\title{
Loop ileostomy versus loop transverse colostomy for temporary fecal diversion after colorectal anastomosis
}

\author{
Abd El-Rahman El-Maraghy, MD; Mahmoud Saad, MD; \\ Mohammed Abdo, MD; Nasser Abd El-Nazeer, MD; Ahmed Kamal, MD; \\ Emad Abd El-Latif, MD; Mostafa Fouad, MD \\ Department of General Surgery, Ain Shams University, Cairo, Egypt
}

\begin{abstract}
Background: Leakage from low colorectal anastomosis could be reduced by using covering stoma to divert fecal stream. Controversy is still present as to whether loop ileostomy (LI) or loop transverse colostomy (LTC) is the optimal method of defunctioning such anastomosis.

Methods: Patients requiring defunctioning following anterior resection or emergency left colonic resection were randomized to receive either LI or LTC. Comparison was made between both groups regarding efficacy \& complications. The minimum follow up after stoma closure was 3 months (mean 10 months).

Results: Between January 2007 and April 2009, 62 patients were randomized into 2 groups (LI 32, LTC 30). There were no significant differences in the mortality, postoperative leakage, stoma prolapse, parastomal hernia, parastomal fistula, incisional hernia, postoperative bowel obstruction, or skin irritation. However, there were significant difference in favour of LI including less evidence of wound infection, less hospital stay, less stomal retraction or necrosis, less time for creation of stoma, less time of bowel transiet and better patient adaptation, while dehydration and time of closure was in favour of LTC.

Conclusion: In this randomized study, both methods appear to provide satisfactory protection method for the low colorectal anastomosis, but LI in general was associated with little complications specially wound infection \& stoma related complications, which favours it as a covering stoma.
\end{abstract}

\section{Introduction:}

Anastomotic leakage is one of the most important surgical complications of colorectal surgery and it has been of great concern due to high occurrence of morbidity and mortality affecting long term survival. ${ }^{1}$

The incidence of clinical anastomosis leakage after resection of the colon and rectum has been reported to vary between 1.8 and 5 per cent, and even as high as 15 per cent in low rectal anastomosis. ${ }^{2}$

Factors that have been found to be significantly associated with anastomotic leakage include male gender, anastomosis below $5 \mathrm{~cm}$ from the anal margin, malnutrition, weight loss and peritoneal contamination at the time of primary surgery. 2,3

The proximal diversion, either by colostomy or an ileostomy; by preventing fecal flow through the anastomosis, minimizes the consequences of the anastomotic leak..$^{3,4}$
Although temporary decompression of colorectal anastomosis by means of loop ileostomy or loop transverse colostomy is accepted by most surgeons, controversy still remains as to whether loop ileostomy or loop transverse colostomy is the best way of defunctioning. 5

The present study is a prospective randomized controlled study aimed to compare the complications and short term outcomes between LI and LTC when used for defunctioning left sided and low rectal anastomosis.

\section{Patients and methods:}

Between January 2007, and April 2009, 62 patients underwent diverting stoma following rectal anastomosis; including 32 patients underwent loop ileostomy (LI) and 30 patients with loop transverse colostomy (LTC). All patients had the site of LI and LTC marked 
before operation and informed consent had been obtained.

The time taken to fashion the stoma was assessed. After operation each patient was reviewed daily to assess daily stoma output and all complications related to the stoma before closure were recorded.

Prior to closure, all patients were subjected to gastrograffin enema to assess anastomotic area. Patients were given prophylactic antibiotic (3rd generation cephalosporins and metronidazole) at induction of anesthesia. All closure procedures were performed using circumstomal incision except for 3 patients (2LI, and 1LTC) in whom midline incision was necessary to be done due to marked adhesion.

The stomas were closed in standard fashion (hand sewn in all cases), under general anesthesia. The time taken to close the stoma, time to passage of 1 st flatus and feces, and postoperative stay were assessed, all complications following closure were noted.

All patients were followed up in out patient clinic \& examined for presence of any complications.

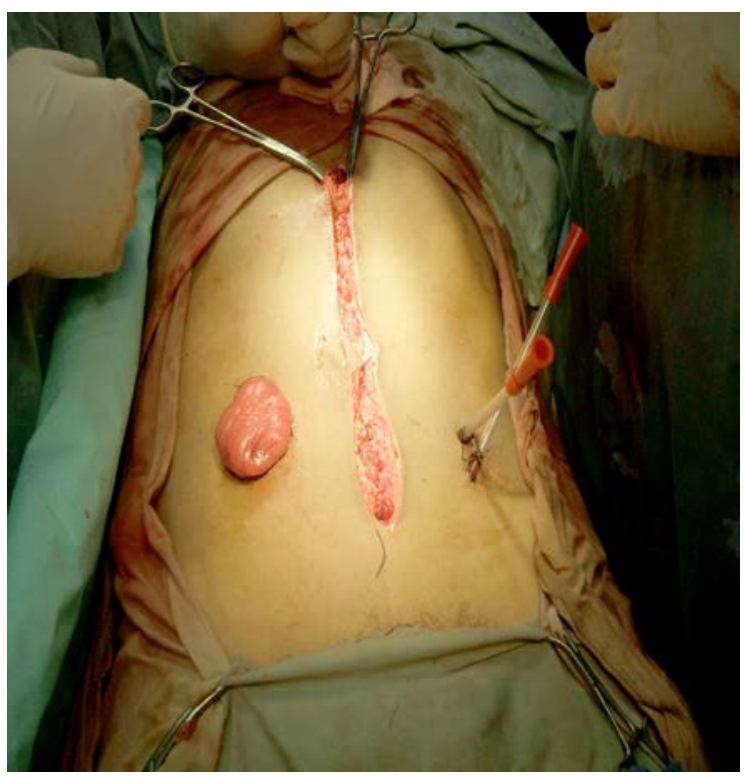

Figure (1): Loop ileostomy.

\section{Results:}

Between January 2007, and April 2009, 62 patients underwent left hemicolectomy and anterior resection, including emergency cases, all cases had colorectal carcinoma except 2 patients with bleeding diverticular disease, one

patient due to iatrogenic bowel perforation, and one due to bleeding rectal angiomatous malformations. The loop stomas were closed in all patients with follow up after closure (3-24 months) mean 10 months.

Table (1): Demographics.

\begin{tabular}{|c|c|c|c|}
\hline S. No. & & $\begin{array}{c}\text { LI } \\
\boldsymbol{n}=\mathbf{3 2}\end{array}$ & $\begin{array}{c}\text { LTC } \\
\boldsymbol{n = 3 0}\end{array}$ \\
\hline 1 & Age & $17-65$ & $19-64$ \\
(years) & $($ mean 54) & $($ mean 48) \\
\hline 2 & Sex & $\begin{array}{c}23 \sigma \\
9\end{array}$ & $\begin{array}{c}22 \sigma \\
8\end{array}$ \\
\hline
\end{tabular}


The data obtained from both groups, were divided into 4 categories: General outcome measures, construction of stoma outcome measures, closure of stoma outcome measures, and functioning stoma outcome measures.

Table (2): General outcome measures.

\begin{tabular}{|c|c|c|c|}
\hline S. No. & $\begin{array}{c}\text { General } \\
\text { outcome measures }\end{array}$ & $\begin{array}{c}\text { LI } \\
\boldsymbol{n}=\mathbf{3 2}\end{array}$ & $\begin{array}{c}\text { LTC } \\
\boldsymbol{n}=\mathbf{3 0}\end{array}$ \\
\hline 1 & Mortality & $\begin{array}{c}1 \\
(3.1 \%)\end{array}$ & $\begin{array}{c}1 \\
(3.3 \%)\end{array}$ \\
\hline 2 & Wound infection & $\begin{array}{c}5 \\
(15.6 \%)\end{array}$ & $\begin{array}{c}12 \\
(40 \%)\end{array}$ \\
\hline 3 & $\begin{array}{c}\text { Length of hospital } \\
\text { stay (Days) }\end{array}$ & $\begin{array}{c}4-8 \\
(\text { mean } 6)(\text { Days })\end{array}$ & $\begin{array}{c}7-12 \\
(\text { mean } 9)(\text { Days })\end{array}$ \\
\hline 4 & $\begin{array}{c}\text { Colorectal anastomotic } \\
\text { dehiscence }\end{array}$ & $\begin{array}{c}1 \\
(3.1 \%)\end{array}$ & $\begin{array}{c}1 \\
(3.3 \%)\end{array}$ \\
\hline 5 & $\begin{array}{c}\text { Dehydration \& } \\
\text { electrolytes disturbance }\end{array}$ & $\begin{array}{c}4 \\
(12.5 \%)\end{array}$ & $\begin{array}{c}0 \\
(0 \%)\end{array}$ \\
\hline
\end{tabular}

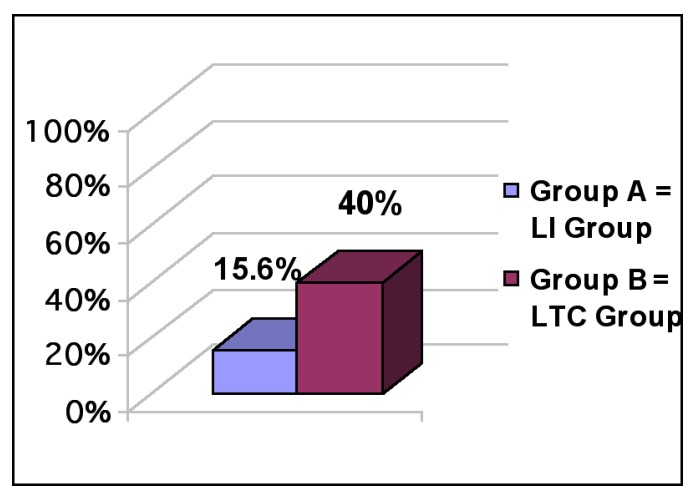

Figure (2): Wound Infection.

For patients who underwent stoma closure, 2 patients died; one after closure by 2 months due to advanced metastatic disease, and one after 10 days of closure due to massive MI (not related to stoma procedure).

In LI group there is less wound infection compared to LTC group which is statistically significant. As regard length of hospital stay, in LI group it took 4-8 days (mean 6 days), while in LTC group it was 7 - 12 days (mean 9 days) (significant statistical difference).
Colorectal anastomotic dehiscence occurred in one patient of both groups which was diagnosed clinically by minor intestinal fluid in the drain and resolved spontaneously on conservative treatment in a period of 2 weeks (no significant statistical difference). Dehydration and electrolyte disturbance (in the form of hypokalemia, which was treated at 1 st by intravenous potassium then changed to oral potassium syrup) were much more in LI group (4 patients), but did not occur in LTC group (significant statistical difference). 
Table (3): Construction of stoma outcome measures.

\begin{tabular}{|c|c|c|c|}
\hline S. No. & $\begin{array}{c}\text { Construction } \\
\text { of stoma } \\
\text { outcome measures }\end{array}$ & $\begin{array}{c}\text { LI } \\
\mathbf{n}=\mathbf{3 2}\end{array}$ & $\begin{array}{c}\text { LTC } \\
\mathbf{n}=\mathbf{3 0}\end{array}$ \\
\hline 1 & Stoma prolapse & $\begin{array}{c}0 \\
(0 \%)\end{array}$ & $\begin{array}{c}0 \\
(0 \%)\end{array}$ \\
\hline 2 & Stoma retraction & $\begin{array}{c}4 \\
(0 \%)\end{array}$ & $\begin{array}{c}4 \\
(13.3 \%)\end{array}$ \\
\hline 3 & Stoma necrosis & $\begin{array}{c}0 \\
(0 \%)\end{array}$ & $\begin{array}{c}1 \\
(3.3 \%)\end{array}$ \\
\hline 4 & Parastomal hernia & $\begin{array}{c}0 \\
(0 \%)\end{array}$ & $\begin{array}{c}1 \\
(3.3 \%)\end{array}$ \\
\hline 5 & $\begin{array}{c}\text { Parastomal fistula } \\
(12.5 \%)\end{array}$ & $\begin{array}{c}0 \\
(0 \%)\end{array}$ \\
\hline 6 & $\begin{array}{c}\text { Time of formation } \\
\text { (minutes) }\end{array}$ & $\begin{array}{c}11-19 \\
(\mathrm{Mean}=15) \\
\text { SD }=3.27\end{array}$ & $\begin{array}{c}20-28 \\
\text { Mean }=25)\end{array}$ \\
\hline
\end{tabular}

For the LI group, no patients had stomal prolapse, retraction, necrosis, parastomal hernia, or parastomal fistula, with less time taken for creation of stoma (mean was 15 minutes in LI group, while in LTC group the mean was 25 minutes) statistically significant difference, while in LTC group 4 patients had stoma retraction, 4 patients had stoma necrosis, (both are statistically significant), one patient had parastomal hernia, and one had parastomal fistula (although present but no significant statistical difference). Patients with stoma retraction, necrosis and parastomal fistula needed reoperation to revise the stoma.

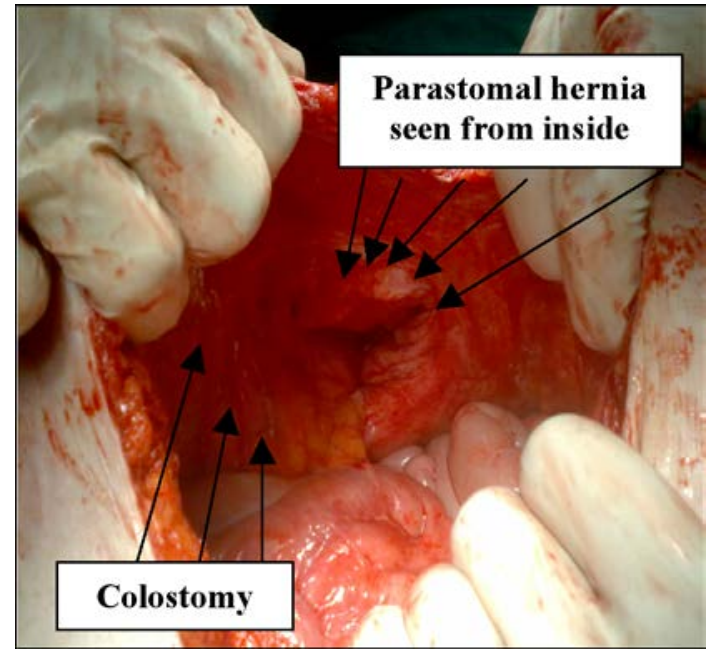

Figure (3): Parastomal hernia seen from inside.

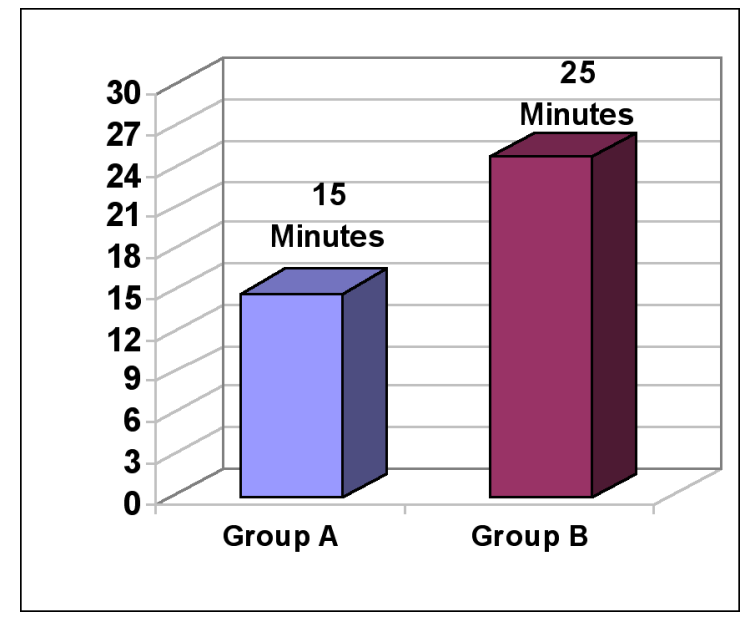

Figure (4): Time of stoma formation. 
Table (4): Closure of stoma outcome measures.

\begin{tabular}{|c|c|c|c|}
\hline S. No. & $\begin{array}{c}\text { Closure } \\
\text { of stoma } \\
\text { outcome measures }\end{array}$ & $\begin{array}{c}\mathbf{L I} \\
\mathbf{n = 3 2}\end{array}$ & $\begin{array}{c}\text { LTC } \\
\mathbf{n = 3 0}\end{array}$ \\
\hline 1 & $\begin{array}{c}\text { Time of } \\
\text { stoma closure } \\
\text { (minutes) }\end{array}$ & $\begin{array}{c}50-124 \\
(\text { mean } 60)\end{array}$ & $\begin{array}{c}40-116 \\
\text { SD } 10.67 \\
\text { SD } 9.97\end{array}$ \\
\hline 2 & Bowel leakage & $\begin{array}{c}0 \\
(0 \%)\end{array}$ & $\begin{array}{c}0 \\
(0 \%)\end{array}$ \\
\hline 3 & Incisional hernia & $\begin{array}{c}0 \\
(0 \%)\end{array}$ & $\begin{array}{c}0 \\
(0 \%)\end{array}$ \\
\hline 4 & $\begin{array}{c}\text { Postoperative } \\
\text { bowel obstruction }\end{array}$ & $\begin{array}{c}2 \\
(6.25 \%)\end{array}$ & $\begin{array}{c}1 \\
(3.3 \%)\end{array}$ \\
\hline
\end{tabular}

LI group took more time to be closed (mean 60 minutes), compared to LTC group (mean 48 minutes) (significant statistical difference).
As regard bowel leakage and incisional hernia at stoma site, no cases were recorded in both groups, while postoperative bowel obstruction was more in LI group, but with no significant statistical difference.

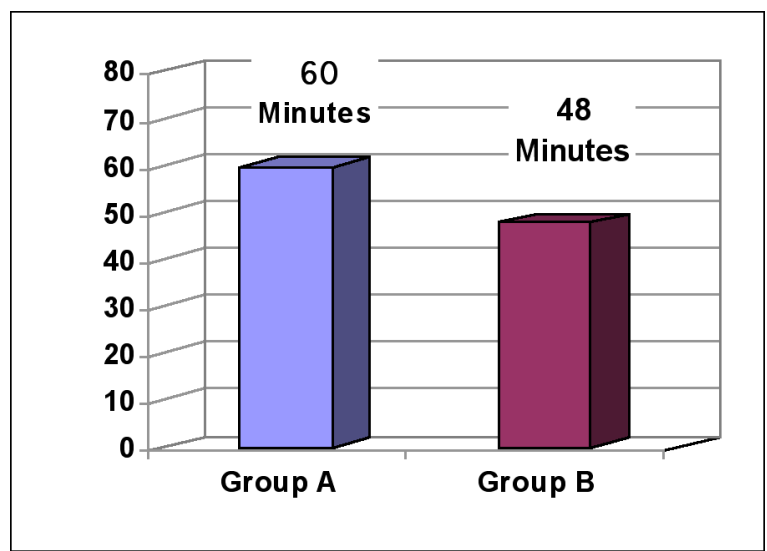

Figure (5): Time of stoma closure.

Table (5): Functioning stoma outcome measures.

\begin{tabular}{|c|c|c|c|}
\hline S. No. & $\begin{array}{c}\text { Functioning stoma } \\
\text { outcome measures }\end{array}$ & $\begin{array}{c}\text { LI } \\
\boldsymbol{n}=\mathbf{3 2}\end{array}$ & $\begin{array}{c}\text { LTC } \\
\mathbf{n = 3 0}\end{array}$ \\
\hline 1 & Skin irritation & $\begin{array}{c}8 \\
(18.75 \%)\end{array}$ & $\begin{array}{c}10 \\
(33.33 \%)\end{array}$ \\
\hline 2 & $\begin{array}{c}\text { Time of bowel } \\
\text { transiet } \\
\text { (time of 1st flatus) }\end{array}$ & $\begin{array}{c}1-5 \\
\text { Mean }=2 \\
\mathrm{SD}=0.6\end{array}$ & $\begin{array}{c}\text { Mean }=4 \\
\mathrm{SD}=0.75\end{array}$ \\
\hline 3 & $\begin{array}{c}\text { Patient adaptation } \\
\text { (leakage } \\
\text { from appliance) }\end{array}$ & $\begin{array}{c}8 \\
(25 \%)\end{array}$ & $\begin{array}{c}18 \\
(60 \%)\end{array}$ \\
\hline
\end{tabular}


From LI group 8 patients experienced skin irritation (i.e. symptomatic alteration of parastomal skin), while in LTC group 10 patients had skin irritation (no significant statistical difference).
As regard time of bowel transiet, it was in favour of LI which took less time (mean $=2$ days), than in LTC group (mean $=4$ days).

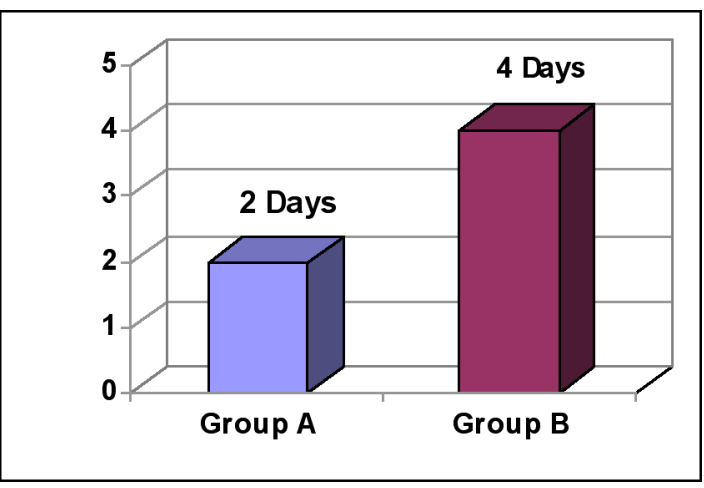

Figure (6): Time of bowel transiet.

LI group was associated with better patient adaptation in the form of less leakage from appliance, compared to LTC group [LI 8 patients (25\%), LTC 18 patients $(60 \%)]$, significant statistical difference.

\section{Discussion:}

Anastomotic leakage is a dread complication of intestinal anastomosis, especially low rectal anastomosis. 1,6

The reported clinical leak rate was 17 per cent in patients with low rectal anastomosis without a defunctioning stoma compared to 6 per cent in a similar group with temporary stoma. $^{7}$

Previous trails had addressed the question of whether LI or LTC is the optimal stoma for defunctioning colorectal anastomosis. In one study, Williams and colleagues 8 found significant difference in favour of LI with regard to odour and appliance changes, and higher wound infection rate associated with LTC closure.

In the present study, there was no significant statistical difference as regard mortality and colorectal anastomotic dehiscence. But LI group was associated with less wound infection. Edward et al., ${ }^{12}$ Williams et al., ${ }^{8}$ and others explained this by the nature of bacterial flora in the stoma as the anaerobic bacterial count from ileostomy fluid is less than 1 per cent compared to normal feces while the colostomy effluent is very similar to that of normal feces and the spout of ileostomy decreases leakage of fecal fluid during mobilization. ${ }^{9,10,12}$

In our study, LI group was associated with less hospital stay compared to LTC group. On the other hand, LI group was associated with increased incidence of electrolyte disturbance and dehydration compared to LTC group. Edward at al. in 2001 and Law in 2002, found also that electrolyte disturbance and dehydration are more common in LI group. ${ }^{12,14}$

In LI group the stoma related complications were less than LTC group including stoma retraction, stomal necrosis (with significant statistical difference), less parastomal hernia, and parastomal fistula (but not proven by significant statistical difference), presence of parastomal hernia in colostomy group could be explained by large fascial defect and wound infection, ${ }^{5}$ where as the occurrence of necrosis and retraction in loop colostomy may be attributed to higher traction and vascular damage, ${ }^{11}$ also Edward et al. in 2001, Gooszen et al. in 1998 and Law et al. 2002, found the same results except for stoma prolapse, Gooszen found it more common in colostomy group. But Sakai in 2001 found it more common in ileostomy group, while Tocchi in 2002 found both groups are equal.12-14,17

Another great difference between both groups was the time of stoma formation which was much less in LI group compared to LTC group. Williams et al. ${ }^{8}$ found the same results in his study, this may be due to the long 
mesentry of small intestine which doesn't need time for dissection compared to LTC group, in which meticulous dissection to prevent compromise of blood supply is an essential step.

Time of stoma closure was significantly higher in LI group compared to LTC group; this is due to the larger defect and less adhesions in LTC group, also no need to excise the spout as in LI group. Other parameters including bowel leakage, incisional hernia, postoperative bowel obstruction had no significant statistical difference. Edward et al. also found that time of closure is less in LI group, but Khoury et al. in 1986 found it equal in both groups. ${ }^{12,17}$

In functioning stoma outcome measures, it was in favour of LI group which showed less time for bowel transiet, this is also present in the study of Khoury in $1986 .{ }^{17}$ Also LI group showed less skin irritation (but not proven statistically), another parameter (patient adaptation) showed more patient satisfaction in LI group indicated by less incidence of leakage from appliance compared to LTC group. Williams et al. ${ }^{8}$ found that ileostomy spout made effluent collection more efficient, induces longer time interval between appliance changes, few of patients complain of odour, also placement of stoma of LTC between the costal margin and waist line and its relative bulk makes it difficult to manage.

\section{Conclusion:}

No specific type of stoma has all advantages and the best available type of decompression couldn't be classified clearly. But so far the results in terms of less wound infection, length of hospital stay, stoma retraction, necrosis, time of stoma creation, time of bowel transiet and better patient adaptation support the choice of loop ileostomy as a technique for fecal diversion for colorectal anastomosis, but still larger scale is needed to verify this.

\section{References:}

1- McArdle CS, McMillane DC, Hole DJ: Impact of anastomotic leakage on long term survival of patients undergoing curative resection for colorectal surgery. Br J Surg 2005; 92(9): 1150-1154.
2- Makela JT, kiviniemi H, Laitinen S: Risk factors for anastomotic leakage after left sided colorectal resection with rectal anastomosis. Dis Colon Rectum 2003; 46: 653-660.

3- Rullier E, Laurent C, Garrelon Jl, et al: Risk factors for anastomotic leakage after resection of rectal cancer. Br J Surg 1998; 85: 355-358.

4- Peeter KCMJ, Tollenaar RAEM, Marijnen CAM, Kranenbarg EK, et al: Risk factors for anastomotic failure after total mesorectal excision of rectal cancer. Br J Surg 2005; 92: 211-216.

5- Güenaga KF, Lustosa SAS, Saad SS, Saconato H, Matos D: Ileostomy or colostomy for temporary decompression of colorectal anastomosis. Cochrane Database of Systemic Review 2007; Issue 1. Art N.: CD 004647. [DOI: 10.1002/ 14651858. CD 004647] Pub2.

6- Moran BJ, Heald RJ: Anastomotic leakage after colorectal anastomosis. Semin Surg Oncol 2000; 18: 244-248.

7- Dehni N, Schlegel RD, Cunningham C, Guiguet M, Tiret E, Parc R: Influence of a defunctioning stoma on leakage rates after low colorectal anastomosis and colonic -J pouch- anal anastomosis. Br J Surg 1998; 85: 1114-1117.

8- Williams NS, Nasmyth DG, Jones D, Smith AH: Defunctioning stomas: A prospective controlled trail comparing loop ileostomy with loop transverse colostomy. Br J Surg 1986; 73: 566-570.

9- Gorbach SL, Tabaqchali S: Bacteria, bile and the small bowel. Gut 1969; 10: 693972.

10-Hill GL: Ileostomy: Surgery, physiology and management. New York: Grune \& Straton, 1976.

11-Barrier A, Martel P, Dugue L, Gallot D, Malafosse M: Direct and reservoir colonicanal anastomoses. Short and long term results. Ann Chir 2001; 126: 18-25.

12-Edward DP, Leppington-Clarke Sexton R, et al: Stoma related complications are more frequent after transverse colostomy than loop ieostomy: A prospective randomized clinical trial. Br J Surg 2001; 88: 360-363. 
13-Gooszen AW, Geelkerken RH, Hermans J, Lagaay MB, Gooszen HG: Temporary decompression after colorectal surgery: Randomized comparison of loop ileostomy and loop colostomy. Br J Surg 1998; 85: 76-79.

14-Law WL, Chu KW, Choi K: Randomized clinical trial comparing loop ileostomy and loop transverse colostomy for fecal diversion following total mesorectal excision. Br J Surg 1986; 73: 566-570.

15-Sakai Y, Nelson H, Larson D, YoungFadok T, Ilstrup D: Temporary transverse colostomy vs loop ileostomy in diversion. Arch Surg 2001; 136: 338-342.
16-Tocchi A, Mazzoni G, Piccini M, et al: Use of ileostomy and colostomy as temporal derivation in colorectal surgery. G Chir 2002; 23: 48-52.

17-Khoury GA, Lewis MC, Meleagros L, Lewis AA: Colostomy or ileostomy after colorectal anastomosis? A randomized trial. Ann $R$ Coll Surg Engl 1986; 69: 5-7. 